\title{
Berberis karnaliensis Bh. Adhikari (Berberidaceae): a new addition to the Flora of India
}

\author{
Umeshkumar L. Tiwari*1, Gopal Singh Rawat ${ }^{2} \&$ Bhupendra Singh Adhikari ${ }^{3}$
}

${ }^{1}$ Foundation for Revitalisation of Local Health Traditions, Bangalore-560106, India; ${ }^{2}$ International Centre for Integrated Mountain Development, Kathmandu, Nepal; ${ }^{3}$ Wildlife Institute of India, P.O. Box 18, Chandrabani, Dehradun, Uttarakhand, India

* corresponding author (e-mail: tigerumesh11@gmail.com)

\begin{abstract}
Berberis karnaliensis Bh. Adhikari, a recently described species was recorded for the first time from the Indian territory. Hence, it is being reported herewith as an addition to the Flora of India. The species differs from its closely related taxon viz. Berberis jaeschkeana Schneid. var. usteriana Schneid. in having coriaceous leaves and 5-6 primary veins on each side of the midrib. Detailed information on taxonomy, morphology, habitat, ecology and distribution of B. karnaliensis as well as photographs and illustrations are provided here for the species identification.
\end{abstract}

Key words: Flora of India, Berberis karnaliensis, Berberidaceae, taxonomy, plant geography

\section{Introduction}

Berberis L. is one of the largest genera under the family Berberidaceae with 450 species distributed in tropical and subtropical regions of northern hemisphere (Ahrendt 1961). This group has maximum representation in the Himalayan region, especially at altitudes between 1500-4000 m a.s.l. Owing to morphological convergence and a short flowering season, an identification of allied taxa is often difficult in the field. Hence, systematic collections and records of distribution are inadequate. During the recent floristic explorations in the Kali Valley, Uttarakhand state of India, we collected an interesting species of Berberis. Based on a perusal of the available literature on Berberidaceae in the Himalaya (Rao \& Hajra 1993; Rao et al. 1998a, 1998b; Uniyal et al. 2007; Tiwari \& Adhikari 2011; Adhikari et al. 2012; Tiwari et al. 2012a, 2012b; Tiwari 2013) and thorough examination of available herbarium specimens from Jumla, Bumra, JSRA 59 (Holotype E, isotype KATH), this species was identified as Berberis karnaliensis Bh. Adhikari. B. karnaliensis has not been recorded from the Indian territory so far. Morphological data were gathered from field studies and herbarium specimens reviewed online in E, KATH, WII and BM (abbreviated according to Holmgren et al. 1990). The data were also consulted with Bhaskar Adhikari. Hence, we provide a brief morphological description with the details of type specimens, ecology, geographic distribution and illustrations to aid identification of the species in the field.

\section{Taxonomic treatment}

Berberis karnaliensis Bh.Adhikari, Edinburgh Journal of Botany 69: 447-522, 2012. Type: Nepal. Jumla, Bumra, JRS A59 (Holotype E!; iso KATH!) (Figs. 1-2). Morphological description: Shrubs up to 2 $\mathrm{m}$ high. Stems and branches terete sometimes slightly angled, densely puberulous when young, becoming less puberulous when older, yellow or yellowish brown, slightly verruculose. Internodes $0.5-2.5 \mathrm{~cm}$ long. Spines usually 3 , sometimes solitary towards twig apex, strong, terete or angular, central spine $1.0-1.5 \mathrm{~cm}$ long, the lateral spines equal to or slightly shorter than the central. Leaves deciduous, thinly coriaceous. Lamina narrowly obovate to narrowly elliptic, $1-3 \times 0.3-1 \mathrm{~cm}$ long, base cuneate, apex acute, rarely obtuse, mucronate, margin usually entire, sometimes with 3-5 spinulose teeth on each side, lustrous green above, paler and slightly papillose beneath, venation subconspicuous above, slightly raised and prominent below. Inflorescence $2-5 \mathrm{~cm}$ long, an umbellate or sub-umbellate raceme of 2-15 flowers. Bracts ovate with acuminate apex, 1.0-1.5 mm long. 


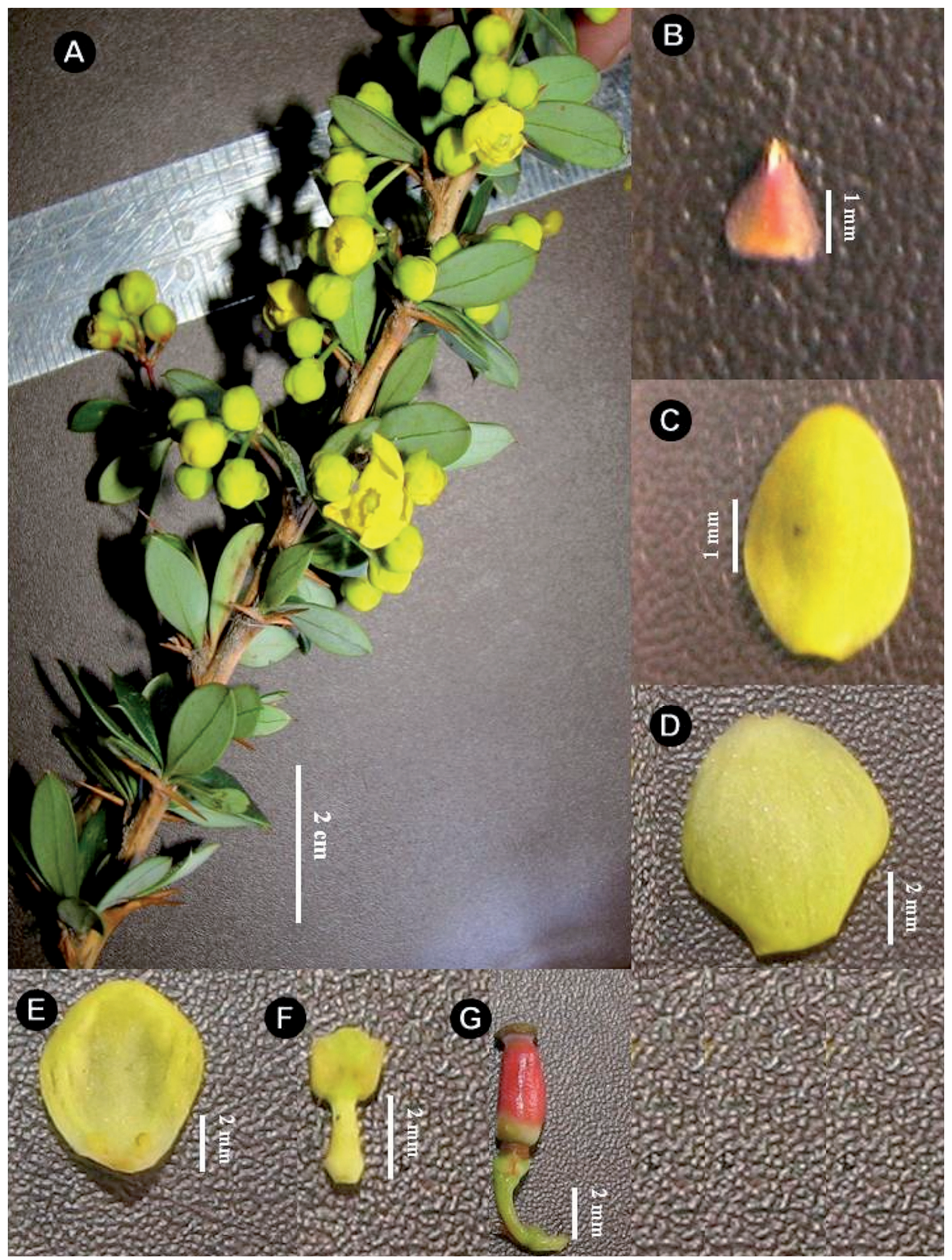

Fig. 1. Berberis karnaliensis Bh. Adhikari (UKT-2104)

Explanations: A - habit, B - outer sepals, C - median sepals, D - inner sepals, E - petal, F - stamen, G - immature fruit

Flowers yellow, $c a .1 \mathrm{~cm}$ in diameter. Peduncle 1.0-2.5 $\mathrm{cm}$ long, glabrous, reddish brown. Pedicel $0.5-1.5 \mathrm{~cm}$ long, glabrous. Sepals in 3 whorls, outer sepals ovate, 1.5-2.0 x 1.0-1.5 mm long; median sepals elliptic or elliptic-ovate, 3-5 x 2-3 mm long; inner sepals obovate to broadly obovate, 5-7 x 3-6 mm long. Petals narrowly obovate to elliptic, 5-7 x 2-4 mm long, base cuneate, margin entire, apex notched, 0.8-1 mm long deep, venation distinct with 1 pair of lateral veins; glands ellipsoid, 0.5-0.7 mm long. Stamens 3-5 mm long, connective 


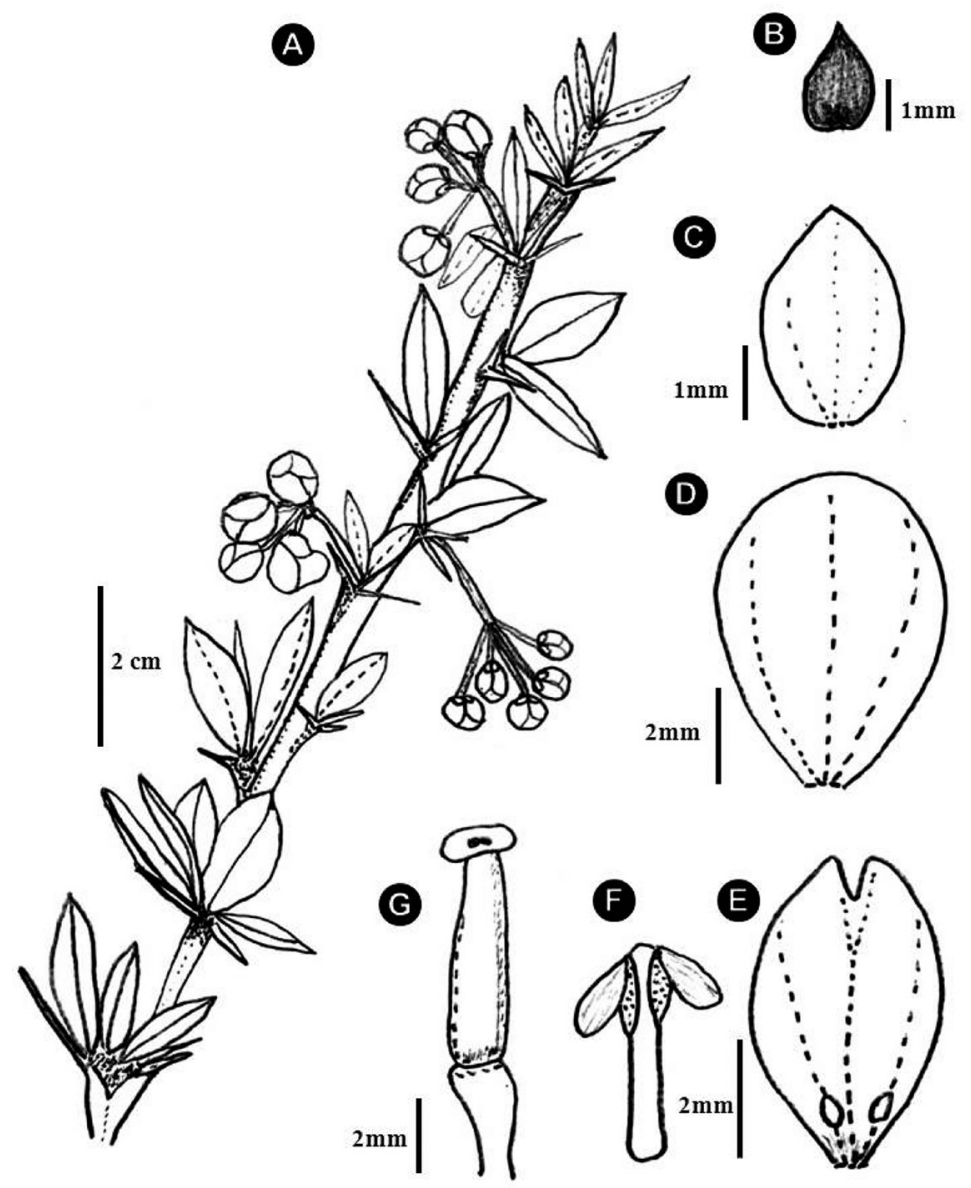

Fig. 2. Berberis karnaliensis Bh. Adhikari: (UKT-2104)

Explanations: A - habit, B - outer sepals, C - median sepals, D - inner sepals, E - petal, F - stamen, G - immature fruit (illustration drawn after UKT-2104 by Umeshkumar Tiwari)

slightly produced, tip obtuse or conical. Pistil 3- $5 \mathrm{~mm}$ long; ovules 2-3. Berries dark red, oblong-obovoid, 0.8-1.0 cm long; style $1 \mathrm{~mm}$ long.

Flowering \& Fruiting. May-June \& JulyAugust.

Habitat and ecology. Frequent along forest edges and canopy gaps, especially associated with Abies spectabilis and Pinus wallichiana. Common along Kali valley, Uttarakhand, at 2500-3200 m a.s.1.

Distribution. This species was described from Nepal, in this paper it is reported for the first time from Uttarakhand, India (Fig. 3).

N o te s. Tiwari (2013) identified the specimens of this taxon as B. jaeschkeana var. usteriana but after critical

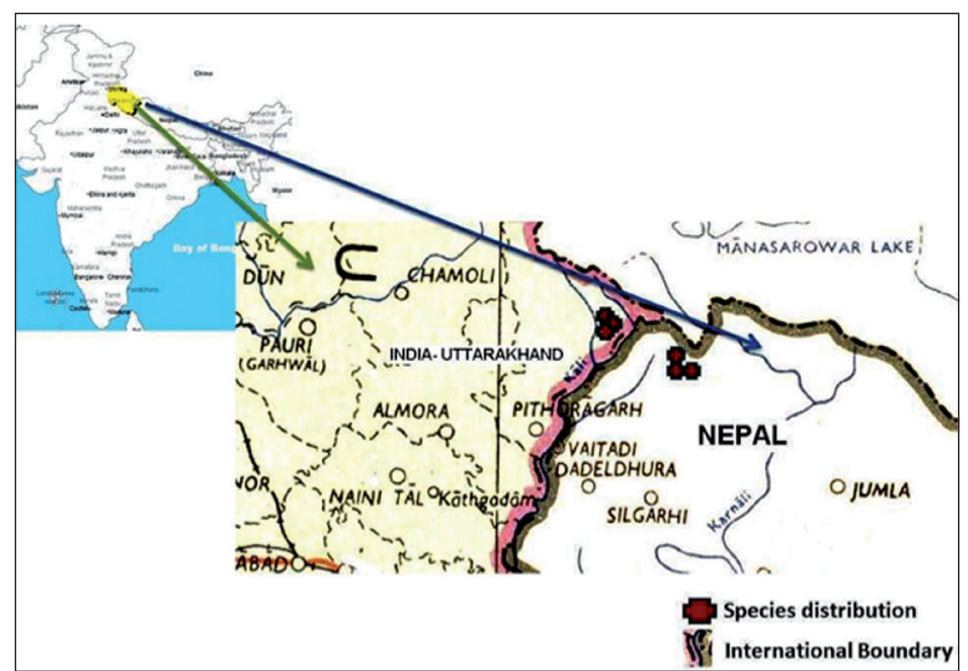

Fig. 3. Distribution of Berberis karnaliensis in India and Nepal (source: mapsofindia.com) 
re-identification and consulting Adhikari et al. (2012), the authors concluded that these specimens belong to Berberis karnaliensis. Both taxa are closely allied. However, B. karnaliensis can be identified based on its densely pubescent branches, long peduncles, umbellate inflorescence and smaller fruits. This species grows commonly along the Kali valley from Gunji village to Kalapani camp, along $9 \mathrm{~km}$ stretch, and was also recorded in the Simikot, Karnali and Rapti zones of western Nepal. Possibly, it may be found in similar habitats in the western Himalaya. Therefore, more information from the western Himalaya is needed to confirm its status. IUCN conservation status is Data deficient (DD).

\section{Specimens examined}

India Kalapani, Kali valley, Pithoragarh, $3574 \mathrm{~m}$, 8 July 2010, Umeshkumar Tiwari (UKT) 2104 (WII);
Kalapani, Kali valley, Pithoragarh, 3456m, 8 July 2010, UKT 2105 (WII); Gunji village, Kali valley, Pithoragarh, 3175m, 8 July 2010, UKT 2106 (WII); Western Nepal. Dolpa, Dunai, 2100 m, 26 April 1974, Dobremez 2781 (E); Dolpa, Kolagaun, 11,000 ft, 3 June 1952, Polunin, Sykes \& Williams 1365 (BM!); Dolpa, Kolagaun, 11,000 ft, 3 June 1952, Polunin, Sykes \& Williams 834 (E!); Rukum, 2700 m, 20 May 1969, Dobremez 142 (BM!).

Acknowledgements. Financial support for the floristic survey was received from the Forest Department of Uttarakhand, Government of Uttarakhand. We are thankful to the Director and Dean of the Wildlife Institute of India, Dehradun, for providing necessary facilities to carry out this work. Thanks are due to Juliet Mc Connell, Image Sales Executive of The Natural History Museum, London, and Sara Edwards, Herbarium Assistant, Kew, London, for providing all the necessary help from Edinburgh (E), BM and Kew to accomplish the present study.

\section{References}

Adhikari B., Pendry C. A., Pennington R. T. \& Milne R. I. 2012. A Revision of Berberis S.S. (Berberidaceae) in Nepal. Edin. J. Bot. 69: 447-522.

Ahrendt L. W. A. 1961. Berberis and Mahonia, a taxonomic revision. J. Linn. Soc. Bot. 57: 1-410.

Holmgren P. K., Holmgren N. H. \& Barnett L. C. 1990. Index Herbariorum, Part 1: the Herbaria of the World, 8th ed., Regnum Vegetabile, vol. 120.

Rao R. R. \& Hajra P. K. 1993. Berberis. In: B. D. Sharma, N. P. Balakrishnan, R. R. Rao \& and P. K. Hajara (eds.). Flora of India 1: 352-402.

Rao R. R., Husain T., Datt B. \& Garg A. 1998a. Revision of the Family Berberidaceae of India-I. Rheedea $8(1): 1-66$

Rao R. R., Husain T., Datt B. \& Garg A. 1998b. Revision of the Family Berberidaceae of India-II. Rheedea 8(2): 109-143.
Tiwari U. L. \& Adhikari B. S. 2011. Berberis rawatii sp. nov. (Berberidaceae) from India. Nordic Journal of Botany 29: 184-188.

Tiwari U. L., Adhikari B. S. \& Rawat G. S. 2012a. A checklist - Berberidaceae in Uttarakhand, Western Himalaya, India. Checklist 8(4): 610-616.

Tiwari U. L., Adhikari B. S. \& Rawat G. S. 2012b. Rediscovery of two endemic species of Berberis from Uttarakhand, Western Himalaya, India. Biodiv. Res. Conserv. 28: 19-24.

TiWARI U. L. 2013. Systematics and Ecology of Berberidaceae in Uttarakhand State. Ph.D. Thesis (unpubl.). Forest Research Institute (Deemed) University, Dehradun, Uttarakhand.

Uniyal B. P., Sharma J. R., Chanudhary U. \& Singh D. K. 2007. Flowering Plants of Uttarakhand (A Checklist). Bishen Singh Mahendra Pal Singh, Dehra Dun. 